\title{
$\longrightarrow$ RUPOS PROTESTANTES E ENGAJAMENTO SOCIAL: UMA ANÁLISE DOS DISCURSOS E AÇÕES DE COLETIVOS EVANGÉLICOS PROGRESSISTAS
}

\author{
Gustavo de Alencar \\ Universidade Federal de Minas Gerais \\ Belo Horizonte - MG - Brasil \\ Orcid: https://orcid.org/0000-0002-1840-1326
}

\section{Introdução}

O segmento evangélico ${ }^{1}$ é um dos mais dinâmicos do cenário religioso brasileiro. Foram muitos os livros, artigos, dissertações e teses discutindo o ativismo social e político de diversas correntes (Campos 2004; Cunha 2007; Freston 1999; Giumbelli 2008, 2013; Mariano 2012). É possível verificar uma enorme diversidade de opiniões, teologias, valores e visões de mundo em seu interior impactando na forma de se relacionarem com a sociedade. Em se tratando de esfera pública e engajamento social, os evangélicos apresentam agendas diversas e, embora muitos trabalhos destaquem seu conservadorismo social e moral, existem vertentes de cunho mais progressista que têm se envolvido com a sociedade a partir de valores muito distintos daqueles que permeiam o imaginário mais difundido sobre evangélicos no Brasil (Cunha 2017; Scheliga 2010). É possível encontrar setores evangélicos que interagem com a sociedade e política propondo transformações balizadas por princípios como justiça social, cidadania e democracia. Este trabalho visa discutir esse ramo progressista evangélico a partir de alguns estudos de caso que iremos apresentar no decorrer do texto.

Servirá como nosso objeto empírico a Frente de Evangélicos pelo Estado de Direito e as ações e discursos do pastor Batista Henrique Vieira. Ambos expressam um pensamento e ativismo político que compõem um ethos evangélico voltado para 
compromissos sociais e valores considerados democráticos. Ao estudar os dois casos, é possível verificar parte do discurso evangélico de caráter mais progressista que entende que a religião possui um papel nas transformações estruturais da sociedade. Tanto a Frente de Evangélicos pelo Estado de Direito quanto o pastor Henrique Vieira possuem certa notoriedade dentro do segmento evangélico progressista, sendo reconhecidos por religiosos e não religiosos, como representantes desse setor. Ao longo dos anos de 2017 e 2018 foi feito trabalho de campo em reuniões e eventos organizados tanto pela Frente de Evangélicos pelo Estado de Direito quanto por organizações das quais Henrique Vieira faz parte. Também foram realizadas entrevistas com o referido pastor, pessoas a ele ligadas e membros e coordenadores da Frente. A pesquisa de campo e as entrevistas feitas para este trabalho encerraram-se em setembro de 2018, de forma que não foi possível perceber as articulações dos agentes religiosos analisados no contexto do segundo turno das eleições ocorridas em outubro de 2018 nem suas estratégias de ação em 2019.

Este texto está situado em uma tradição mais longa de estudos da sociologia da religião do país que, desde a década de 1960, tem privilegiado a análise da religião como um fator de mudança social. Na gênese dos estudos sociológicos sobre os evangélicos brasileiros, observou-se a ênfase em análises funcionalistas que buscavam na teoria da modernização as bases para a interpretação do fenômeno a ser estudado (Camargo 1971; D’Epinay 1970; Souza 1969). Crescendo desde a década de 1930 40, os evangélicos, principalmente em sua vertente pentecostal, chamavam a atenção dos pesquisadores por seu crescimento nas grandes cidades na segunda metade do século XX. Neste período, surgiu uma série de pesquisas que explicava o crescimento evangélico a partir de suas funções na sociedade que passava por transformações intensas. Era comum entender que a fé evangélica respondia às necessidades de adaptação dos indivíduos inseridos em um país que se modernizava (Mariano 2011). Parte do desenvolvimento da sociologia da religião que se debruçou sobre os evangélicos procurou confirmar ou rejeitar essa tese, fazendo avançar a discussão principal que associava os evangélicos com processos de mudança social.

Também neste artigo os grupos religiosos serão analisados a partir de suas relações com processos sociais mais amplos que concernem à mudança social. $\mathrm{O}$ pentecostalismo, de maneira especial, atraiu a atenção dos estudiosos de meados do século XX por ser uma religião nova no que tange a sua expressão pública e, por isso, possuía um potencial para transformar as estruturas da sociedade. A questão central girava em torno de saber qual papel essa religião desempenhava nos processos de modernização e nas instituições em desenvolvimento como educação, mercado de trabalho, eleições, capitalismo, entre outras. Alguns diagnósticos (Camargo 1971, 1973; D’Epinay 1970; Souza 1969; Velasques Filho e Mendonça 1990) indicavam que os pentecostais tinham seu papel muito mais ligado à conservação do status quo e das estruturas sociais vigentes do que propriamente de mudança social. No entanto, como os evangélicos são heterogêneos no que tange a sua teolo- 
gia e ao seu envolvimento com a sociedade, o seu papel e participação na sociedade pode variar bastante.

Neste trabalho, poderemos verificar que os agentes religiosos que nos servem de caso empírico desenvolvem discursos e ações que incentivam o engajamento do fiel e da igreja na transformação do mundo em contraposição a um modelo de religião entendido como conservador. Busca-se desenvolver uma espiritualidade engajada na construção de uma sociedade considerada mais justa, democrática e inclusiva nos termos assimilados por esses grupos. A Frente de Evangélicos pelo Estado de Direito e o pastor Henrique Vieira, cada um à sua maneira, buscam romper com um certo estigma a respeito dos evangélicos que os conecta automaticamente com radicalismo, fundamentalismo e conservadorismo. Ao disputar a identidade evangélica e o sentido do que é ser um cristão evangélico, cada um desses atores religiosos atua publicamente em busca de legitimidade perante a sociedade civil e os evangélicos como um todo.

\section{Tipologias do envolvimento dos protestantes com a sociedade}

Desde sua inserção no Brasil no século XIX², os protestantes tiveram diferentes formas de envolvimento com a cultura e com a sociedade. Em um primeiro momento, conforme descrito por Antonio Gouvêa Mendonça (2004), o chamado protestantismo de missão, advindo da Europa e Estados Unidos, apresentou uma retração no que tange ao envolvimento social, pois construiu guetos culturais que rejeitavam o "mundo" e o secular, considerando-os como riscos para a fé dos fiéis. A missão do evangélico, nessa concepção sectária, era pregar o evangelho, converter pessoas e insistir na santificação dos indivíduos para tornar o mundo "menos influenciado pelo pecado". Para mudar o mundo era necessário transformar as "mentes" e os "corações" das pessoas. Essa transformação só poderia ser feita através do "poder do evangelho", da pregação da palavra, oração e leitura da bíblia, que levaria o convertido a se tornar uma "nova criatura". Basicamente, o evangélico era aquele que, afastado da cultura, não bebia, não fumava, não apostava em jogos de azar, não frequentava teatro ou cinema, não se envolvia com política nem com ciência já que todas essas atividades eram consideradas "mundanas" e podiam afastar o crente dos caminhos de Deus (Cavalcante 2010).

Nas últimas décadas do século XX, no entanto, muita coisa mudou no que se refere à presença evangélica em nossa sociedade. Ao contrário de um certo sectarismo religioso que caracterizou parte da atuação evangélica na sociedade durante parte do século XX, nas três décadas finais essa religião tem se mostrado extremamente dinâmica no seu envolvimento em questões públicas e culturais, como tem sido bem documentado (Campos 2004, 2005; Cunha, 2007; Freston 1999; Giumbelli 2002, 2008, 2013). Essa mudança na participação dos evangélicos na sociedade expressa-se nos dados do último Censo realizado pelo IBGE em 2010. Os dados divulgados em 
2012 apontam os evangélicos compondo 22,2\% da população, cerca de 42 milhões de indivíduos para uma população contabilizada em 190 milhões, em comparação com os dados de 1980 que mostrava os evangélicos compondo 6,6\% da população (Camurça 2013:63).

O crescimento numérico dos evangélicos no Brasil nas últimas décadas foi acompanhando de uma maior presença na cultura e sociedade brasileira. Emerson Giumbelli (2013) utiliza o termo "cultura pública" para designar o tipo de presença na sociedade e o engajamento cultural que caracteriza os evangélicos no Brasil de hoje. Giumbelli, para exemplificar a cultura pública evangélica, apresenta os seguintes casos: a participação na mídia através dos exorcismos na TV e pregações facilmente encontradas nos canais evangélicos; shows e eventos realizados em praças, ruas, avenidas, como a "Marcha para Jesus"; organizações como os Atletas de Cristo que criam grupos de oração e de apoio em agremiações esportivas; a presença dos evangélicos em diversos meios considerados como pontos de pregação e conversão, como prisões, hospitais e até mesmo transporte coletivo como trens, ônibus e metrô; práticas de oração e meditação coletiva feitas muitas vezes em locais elevados da cidade, como montes; alterações da paisagem urbana através da construção de templos e "catedrais" de grande porte (Giumbelli 2013).

Os exemplos oferecidos por Giumbelli (2013) demonstram que a maior presença evangélica na sociedade se dá pelo que pode ser chamado de ética do domínio. São marcas da ética do domínio a noção de que o cristão deve se envolver em uma batalha espiritual que visa disputar cada espaço da sociedade e ganhá-la para Jesus (Mariz 1999; Rosas 2015). A realidade é entendida como sendo marcada por entidades demoníacas chamadas "potestades" e "principados" que precisam ser enfrentadas para que a vontade de Deus seja feita. Cada aspecto da realidade passa a ser disputado no entendimento de que tudo se trata de uma batalha espiritual na qual o cristão deve se engajar. O propósito da ética do domínio é se envolver na sociedade conquistando-a para Jesus, moralizar o país e fazer avançar os princípios do evangelho, tal como entendido por esse setor, sobre cada dimensão da existência. Essa ética possui impactos na esfera pública e na conformação de comportamentos de uma parcela significativa da população.

Se, por um lado, os evangélicos apresentam uma ética contracultural de afastamento da sociedade e, por outro, uma ética do domínio em que cada setor da sociedade é visto como um ponto de pregação evangélica a ser disputado, existe uma terceira via de engajamento com a cultura. Neste terceiro caso, a via de interação de evangélicos com a sociedade visa ao desenvolvimento de um ethos sociorreligioso que tem como propósito transformar a sociedade a partir de princípios democráticos e de justiça social que são interpretados como compatíveis com o cristianismo evangélico. Trata-se de evangélicos de cunho progressista que entendem que a fé cristã deve oferecer respostas para questões sociais como desigualdade, violência urbana, pobreza, desemprego, corrupção, analfabetismo, mortalidade infantil, entre outros, e 
ter como missão a concretização do Reino de Deus entendido como uma realidade de paz e justiça para todos - temas econômicos, políticos e sociais. Não há um esforço sistemático e preocupação de conversão de indivíduos que não são convertidos por parte desses setores. Seus discursos visam muito mais à mudança na forma de pensar de pessoas que já são evangélicas, no sentido de que elas precisam valorizar as dimensões sociais e políticas de sua fé.

Há mais de meio século protestantes brasileiros de cunho progressista ensaiam a consolidação e formação de uma ala progressista no país. Grupos, instituições e lideranças, a partir da década de 1950, produziram recursos teóricos, conceituais e práticos que orientaram cristãos em um engajamento que levasse em consideração os elementos estruturais do contexto social no qual o fiel e a igreja estavam inseridos. Flávio Conrado (2006), em sua tese a respeito das práticas e estratégias desenvolvidas por coletivos evangélicos em torno da "ação social", demonstra alguns exemplos de grupos evangélicos que se colocaram publicamente em defesa de noções como justiça e ação social. Baseados principalmente pela Teologia da Missão Integral ${ }^{3}$ e em diálogo com o movimento ecumênico, grupos como Visão Mundial, Associação Evangélica Brasileira (AEVB), Rede Evangélica Nacional de Ação Social (RENAS), entre outras instituições evangélicas, procuraram redefinir o papel dos evangélicos na sociedade brasileira.

Na avaliação de Flávio Conrado (2006), a emergência de redes evangélicas articuladas em torno da assistência social é explicada pelo desenvolvimento de uma cultura cívica que ganhou força no país a partir do período de redemocratização no final da década de 1980. Através de discursos religiosos alicerçados em uma noção de responsabilidade social que deveria ser seguida pelos cristãos, as redes evangélicas de assistência buscaram ampliar a participação social dos evangélicos atendendo à demanda por cidadania que estava em uma crescente no país. Igrejas evangélicas e instituições paraeclesiásticas em parcerias com ONGs, instituições governamentais, movimentos sociais, sindicatos, universidades desenvolveram ações voltadas para assistência a crianças e adolescentes em situação de vulnerabilidade social, campanhas a favor do desarmamento e contra a violência em seus diversos níveis, ações educacionais, assistência médica e outros serviços de saúde, etc. Sendo assim, surgia uma nova forma de ser evangélico que se evidenciava na década de 1990 e 2000. A via da assistência social e da filantropia pode ser entendida como uma das maneiras de alguns grupos evangélicos alcançarem legitimidade no interior da sociedade brasileira. Ao dar visibilidade às suas ações e impactar setores da sociedade, igrejas evangélicas e entidades paraeclesiásticas afirmaram-se no campo da ação social do país e disputaram espaço na sociedade com outras correntes do segmento evangélico (Conrado 2006:80-81).

\section{A Frente de Evangélicos pelo Estado de Direito}

O primeiro grupo analisado neste artigo é a Frente Evangélica pelo Estado de Direito (FEED), que surge em 2016 no contexto do impeachment de Dilma Rousseff. 
Uma rede formada por líderes cristãos iniciou um movimento de articulação contrapondo-se ao impeachment e acusando a ocorrência de um golpe de Estado no país orquestrado pela mídia e pelo poder Legislativo. $O$ pastor Ariovaldo Ramos, coordenador nacional da FEED, assim como a maior parte dos integrantes do movimento, adota em suas pregações e discursos princípios da chamada Teologia da Missão Integral (TMI).

A Teologia da Missão Integral (TMI) é uma forma de pensar a fé que surgiu por volta da década de 1970 nos setores do protestantismo de missão latino-americanos. Tratava-se de um setor da igreja protestante que rejeitava o fundamentalismo religioso e o pouco envolvimento com a sociedade. Era comum no período associar aqueles que, dentro do movimento evangélico, se preocupavam com os problemas sociais ao chamado liberalismo teológico ${ }^{4}$ e com a recusa de aspectos caros à identidade evangélica como oração, tarefa evangelizadora e desenvolvimento da espiritualidade pessoal. Também aqueles que se recusavam a se envolver com qualquer tipo de questão social eram entendidos como fundamentalistas. Para superar essa suposta dicotomia entre liberais e fundamentalistas, um grupo de teólogos, pastores e missionários latino-americanos desenvolveu os contornos da Teologia da Missão Integral (TMI):

\begin{abstract}
A Teologia Evangélica da Missão Latino-americana é também conhecida no cenário teológico protestante-evangélico como a Missão Integral da Igreja. Ela é o saber da fé que se compreende enviada por Deus ao mundo, para uma ação integral, em prol da sua transformação. Surgiu como resultado do esforço de pastores, líderes ministeriais, missionários, professores e teólogos evangélicos, na busca pela identidade da igreja evangélica latino-americana e a sua maneira específica de elaborar sobre a fé missionária que professavam. Eram pessoas comprometidas com a tradição protestante-evangélica, mas também com a realidade sócio -histórica e cultural da América Latina. (Sanches 2009:55)
\end{abstract}

Arraigada na tradição do movimento missionário que visava espalhar a mensagem do evangelho em todos lugares do mundo, a Teologia da Missão Integral enfatizou a necessidade de se pensar a América Latina como um contexto missionário específico que exigia adaptações próprias à realidade encontrada em seus países. A palavra "integral" serve para enfatizar que esta teologia não está preocupada apenas com as dimensões "espirituais" como busca por santidade individual, prática da oração e meditação, leituras pessoais da bíblia, jejuns etc. $\mathrm{O}$ ser humano é integral na visão da TMI e, por isso, apresenta uma dimensão econômica, social e cultural que precisa ser levada em conta pelos missionários evangélicos - principalmente por aqueles que atuarão na América Latina. Um dos lemas da TMI é "o evangelho todo para o homem todo e para todos os homens". Sendo assim, a missão da igreja e dos cristãos no mundo deve considerar todas as dimensões, inclusive as sociais, econômicas e culturais dos indivíduos que irão "receber o evangelho". 
Na tentativa de operacionalizar os princípios da dimensão social e política da fé, o pastor Ariovaldo Ramos, juntamente com outros líderes, fundou a Frente de Evangélicos pelo Estado de Direito com o intuito de atuar na sociedade e demonstrar que nem todos os evangélicos participaram do "golpe de Estado". Ariovaldo Ramos e outras lideranças formularam em março de 2016 um Manifesto que, em seu prelúdio, contém as seguintes palavras:

A Frente de Evangélicos pelo Estado de Direito é um movimento, nascido no meio cristão evangélico, com os objetivos de promover a justiça social, a defesa de todos os direitos garantidos pela constituição brasileira (direitos civis, políticos, sociais, econômicos, culturais, etc.) e pela legislação internacional de direitos humanos, enfrentar quaisquer violações de direitos humanos, lutando pela garantia do Estado Democrático de Direito.

A Frente surge em um momento de grande crise, aflição, angústia e incitação ao ódio, vividos pela nação brasileira, com ataques frontais ao pleno exercício da democracia. A ausência de serenidade e cautela nestes momentos críticos tem despertado muita preocupação e teme-se que o acirramento provocado pela ruptura democrática venha custar mais vidas humanas (Frente de Evangélicos pelo Estado de Direito 2016).

Esse documento pode ser assinado por qualquer um que o acessar através da internet. No primeiro mês, já eram cerca de quatro mil assinaturas. Verifica-se ao longo do manifesto uma defesa de valores democráticos e a acusação contra impedimentos que cerceiem a sua concretização na sociedade brasileira. Em palestras e em conversas com o pastor Ariovaldo Ramos realizadas durante a pesquisa, foi possível perceber que, em sua análise, a Frente de Evangélicos pelo Estado de Direito tem sido eficaz em promover um espaço de resistência evangélica relevante. Para esse líder, a Frente de Evangélicos deve servir como contraponto histórico à forma como alguns agentes religiosos têm agido no país de maneira a impedir direitos e ir contra princípios democráticos. O referido pastor acredita que a FEED é um dos grupos evangélicos envolvidos com os princípios de responsabilidade social da igreja que mais cresce no país e na América Latina. Parte da atuação de Ariovaldo Ramos nos últimos dois anos tem sido participar de debates, encontros, palestras em universidades, igrejas, sindicatos para tentar difundir as visões da Frente de Evangélicos e aumentar a capacidade do grupo em se tornar uma referência para evangélicos que buscam conciliar sua identidade cristã com uma luta social de cunho progressista.

Por se tratar de um coletivo de evangélicos que entende como parte de sua missão o envolvimento em conflitos políticos e conjunturas sociais, a Frente de Evangélicos pelo Estado de Direito realiza notas oficiais sobre assuntos que estão em debate na esfera pública. Um exemplo recente foi a formulação de uma nota em 28 de 
setembro de 2018 que começa com a seguinte pergunta "Pode um crente votar em Bolsonaro?", para, em seguida, apresentar uma reflexão a respeito da questão:

Nós, da Frente de Evangélicos pelo Estado de Direito, compomos um movimento formado por crentes em Cristo Jesus. Fazemos parte das mais variadas igrejas e denominações e além da fé, possuímos a certeza de que a democracia é um sistema que permite a garantia de direitos e a construção da cidadania plena.

Assim - diante de tantas cartas e posições de líderes religiosos que reconhecem a candidatura de Bolsonaro como messiânica - nos manifestamos contra as suas posições, levantando nossa voz em nome da justiça, como fizeram os profetas, os primeiros cristãos e milhares de crentes ao longo da história.

Levantamos nossa voz contra a violência, contra o machismo, contra o racismo, contra o preconceito, contra o sexismo, contra o autoritarismo e contra a exclusão manifestadas por Bolsonaro no exercício na vida política, e em seu excludente programa de governo, divulgado como solução para a realidade brasileira. [...]

Sabemos que o Evangelho de Jesus Cristo defende a vida de todas as pessoas, especialmente a vida dos mais fracos, física, social, econômica, educacional, racial e moralmente. Foi entre essas pessoas que Jesus andou, tendo sido, ele mesmo, uma delas. Por isso, e por todos os brasileiros, reconhecemos que a candidatura de Bolsonaro é alimentada pelo ódio, sendo o oposto à proposta do Evangelho, daquele que sendo Deus se fez humano e habitou entre nós.

Assim, convidamos o povo evangélico a repudiar as posições esboçadas por essa candidatura que propaga o ódio ao próximo e nega valores básicos do Evangelho, além de ameaçar o restabelecimento da democracia no Brasil. Afinal, como lembra e exorta o apóstolo, foi para a liberdade que Cristo nos libertou. Portanto, permaneçamos firmes e não nos deixemos submeter novamente a um jugo de escravidão. (Frente de Evangélicos pelo Estado de Direito 2018)

A nota ainda menciona um posicionamento contrário à liberação do porte de armas, à tortura e à misoginia que seriam associadas ao referido candidato. No entendimento da Frente de Evangélicos pelo Estado de Direito, é parte do papel cristão e da igreja posicionar-se em favor da democracia e defendê-la contra aquilo que é interpretado como ameaça. A conjugação da retórica religiosa com noções seculares como direito, liberdade e democracia faz parte da estratégia do grupo de se legitimar publicamente e perante seu nicho religioso que carece de uma gramática religiosa 
para dar sustentação ao seu envolvimento social. Para atuar na vida pública com legitimidade, grupos religiosos frequentemente mobilizam uma linguagem secular sem a qual não seria possível ter espaço diante de não religiosos. Em seus esforços de buscar legitimidade, tanto a FEED quanto o pastor Henrique Vieira realizam a tradução de princípios religiosos para uma linguagem pública que esses grupos desenvolvem a respeito de direitos, democracia e justiça social.

A Frente opera através de uma coordenação nacional, coordenações dos núcleos locais de cada estado e um conjunto de pessoas que esporadicamente participam de eventos promovidos pelos organizadores. Os núcleos locais estaduais possuem autonomia para desempenhar as atividades que acharem relevantes em sua localidade. A coordenação nacional da Frente orienta que essas atividades tenham como mote principal a defesa da cidadania e da democracia e que sejam evitados debates teológicos denominacionais que podem proporcionar desagregação. $\mathrm{Na}$ opinião de Ariovaldo Ramos, a eficácia da Frente de Evangélicos pelo Estado de Direito decorre da sua capacidade de organizar evangélicos de diferentes ênfases teológicas que lutam por justiça social e efetivação de direitos sem dar lugar para disputas teológicas específicas que podem servir, segundo ele, como fator desagregador. $\mathrm{O}$ argumento é que, ao tratar de temas considerados polêmicos como homossexualidade, interpretações teológicas, aborto, entre outros, pessoas que militam na Frente poderiam se sentir desencorajadas a fazer parte do grupo. Já que a proposta inicial da FEED era apenas criticar tanto o que foi entendido como um golpe contra Dilma quanto as agendas de governo colocadas em prática pela gestão de Michel Temer, muitas pessoas que participam da Frente são conservadoras em sua forma de pensar a teologia e a sociedade, embora possuam posicionamentos sociais e políticos mais à esquerda no que tange a pautas econômicas. Sendo assim, para não fazer com que pessoas com perfil teológico conservador saiam do movimento, a Frente não assume abertamente debates teológicos. Nesta visão, discutir homossexualidade e aborto implicaria fazer revisões teológicas a respeito de noções como as de pecado, santidade, missão do cristão etc. Por isso, um outro argumento utilizado pela Frente para não participar de discussões dessa natureza é que ela é um movimento político organizado por evangélicos e não uma igreja ou um coletivo voltado exclusivamente para a dimensão espiritual.

$\mathrm{Na}$ visão de evangélicos progressistas com mais articulação com as pautas trazidas pelos movimentos sociais, a falta de participação da Frente de Evangélicos pelo Estado de Direito nos debates de cunho teológico em busca de uma fé e espiritualidade mais aberta para o tema da sexualidade, por exemplo, enfraquece a representatividade do movimento em se dizer de alguma forma a favor da cidadania e democracia. Em entrevistas realizadas, foram coletadas críticas à FEED feitas por evangélicos progressistas que entendiam que era necessário discutir abertamente temas como a descriminalização do aborto, por exemplo, compreendendo que essa pauta representaria a expansão da autonomia, da liberdade e do direito da mulher sobre seu próprio corpo. Desta forma, o tema do aborto teria ligação com a cidadania e luta por direitos 
e, por isso, a FEED deveria, de acordo com a opinião de alguns, trabalhar esses assuntos de maneira mais direta. Alguns evangélicos progressistas entrevistados disseram não participar da Frente por causa de sua recusa em discutir abertamente a pauta dos direitos LGBT e reprodutivos.

No que tange a sua organização, a Frente de Evangélicos possui núcleos estaduais que promovem ações dentro das intenções principais do Manifesto de Fundação sem que haja uma diretriz clara sobre qual atividade deve ser feita. Em Belo Horizonte, um núcleo da Frente começou a ser formado a partir do ano de 2017, mais precisamente, do mês de maio, através da articulação de cristãos evangélicos que se alinhavam com as perspectivas apresentadas pelo movimento nacional e se conheciam de outros contextos de militância evangélica. Na reunião inicial de fundação do núcleo da FEED em Belo Horizonte, foi enfatizado que a missão da igreja, a missão do cristão, em especial do evangélico era

[...] cuidar dos pobres, dos que sofrem com a violência e miséria, dos que sofrem com a homofobia e com o machismo e de todos os preconceitos e discriminações que tornam precárias as relações entre filhos e filhas do mesmo pai. O chamado da Frente Evangélica é esse chamado de compreender que nossa fé ou serve [no sentido de serviço] ou não serve para nada [no sentido de não ser útil]. (trecho do caderno de campo, 29/05/2017)

Desde maio de 2017, tenho participado das atividades promovidas pelo núcleo da Frente de Evangélicos pelo Estado de Direito em Minas Gerais. Após um período de adaptação e consolidação dos seus participantes, a Frente tem se organizado desde 2018 em torno de eventos para fortalecer uma cultura democrática e um pensamento teológico voltado para a noção de justiça social e responsabilidade social da igreja. $\mathrm{O}$ grupo de coordenadores é formado por pessoas de classe média com alta escolaridade e que frequentam igrejas evangélicas geralmente de denominações e contornos teológicos alinhados ao protestantismo histórico. O perfil dessas igrejas na maior parte dos casos é de pessoas conservadoras no que tange à política e à agenda moral. Desse modo, os participantes da FEED em seu núcleo Minas relatam constantes conflitos e indisposições com lideranças e membros de sua comunidade de fé. Por conta de embates motivados por questões teológicas e políticas, algumas pessoas membros da FEED optaram por se afastar da igreja por entender que nela havia um pensamento conservador e pouco voltado para dimensões sociais. Outras, mesmo com conflitos e discordâncias, preferem permanecer em suas igrejas na tentativa de convencer as pessoas daquilo que consideram a verdadeira missão da igreja e do cristão. Essas pessoas têm na FEED um espaço onde conseguem conciliar sua identidade evangélica com sua atuação progressista na política e em assuntos sociais, já que, em suas igrejas, não têm espaço para apresentar suas opiniões políticas e encontrar pessoas que concordam. 
A FEED em Minas Gerais tem atuado na promoção de eventos, encontros e rodas de debates que servem de espaço propício para o reforço da identidade evangélica atrelada a noções de responsabilidade social e busca por justiça. Um dos eventos realizados é o "Café da manhã com os pastores" que ocorre a cada dois meses e no qual o pastor Ariovaldo Ramos realiza uma palestra que tem como alvo principal lideranças evangélicas da cidade. Geralmente participam cerca de vinte pessoas que compartilham os princípios da missão integral e, por isso, acreditam que o papel do cristão e da igreja é se envolver com a responsabilidade social e a luta por justiça. Outro evento organizado pela FEED em Belo Horizonte é "De Frente com a Frente", que é um encontro temático no qual são chamados especialistas, não necessariamente evangélicos, para debater assuntos de interesse público. Foram quatro encontros até o mês de setembro de 2018: em maio, o "Cristo e as ocupações"; em junho, o "Cristo e violência contra as mulheres"; em agosto, o "Cristo e a Teologia Negra ontem e hoje”; e no mês de setembro, "Religião e política, sim; Igreja e Estado, não!". Como o trabalho da FEED núcleo Minas é feito por voluntários que não possuem orçamento próprio, o sucesso ou não dos eventos depende do tempo dos organizadores de planejá-lo e divulgá-lo e da capacidade de fazer "vaquinhas" para comprar lanches coletivos e fazer bandeiras e camisas que ajudem a divulgar os ideais da FEED. Dos encontros "De Frente com a Frente", participam em torno de 30 e 35 pessoas quando são considerados cheios e de 10 a 15 pessoas quando são considerados vazios. A maior parte do público são pessoas evangélicas que se alinham com discussões sociais de esquerda e estão em busca de instrução e reforço de sua identidade enquanto religiosos progressistas.

A FEED não tem como sua atividade foco a evangelização e conversão de pessoas que não são cristãs. Sua atuação se dá mais na dimensão da missão do cristão, ou seja, na discussão daquilo que o evangélico, uma vez que adere à fé cristã, deve fazer para cumprir seu propósito e missão enquanto religioso. Por isso, sua atuação depende da obtenção de legitimidade perante o público cristão evangélico mais amplo. Como nos dias atuais o segmento evangélico tem se engajado em agendas bem diferentes daquelas defendidas pela Frente, esta é constantemente acusada de não ser verdadeiramente evangélica e de se tratar de um grupo de militantes políticos que fingem ser religiosos. Para lidar com esse tipo de acusação, a Frente busca sempre articular sua retórica política valendo-se de elementos da ortodoxia cristã e, por isso, em seus manifestos, reuniões e eventos, existem momentos de oração, leitura de versículo bíblico e até sermões. Sua consolidação na cidade de Belo Horizonte como um grupo evangélico legítimo dentro do seu próprio segmento para discutir temas sociais e políticos ainda está para ser verificada. Por se tratar de um grupo jovem, existe muita expectativa dentre os membros que participam da Frente para que ela consiga cada vez mais legitimidade perante o público não religioso como partidos políticos, movimentos sociais e centros universitários, contribuindo, assim, com uma visão cristã evangélica a respeito do tema. O que a Frente já proporciona é um espaço no qual 
evangélicos sejam capazes de conciliar sua identidade religiosa com seu engajamento social mais à esquerda, reforçando seus compromissos tanto com a religião quanto com sua militância política.

\section{Pastor Henrique Vieira, Entre.nós e Esperançar}

O outro ator religioso escolhido para servir de base para a análise dos discursos progressistas é o pastor Henrique Vieira. Com 31 anos de idade, o pastor Henrique Vieira iniciou sua trajetória evangélica junto com sua família em uma igreja chamada Primeira Igreja Batista de Niterói (RJ) e, logo na adolescência, ao desempenhar funções na igreja como aulas, coral, cursos, liderança de grupos de adolescentes, decidiu que queria ser pastor. Formou-se em Histórica, Ciências Sociais e Teologia, e, hoje, é pastor da Igreja Batista do Caminho, uma dissidência da Primeira Igreja Batista de Niterói (RJ). Henrique Vieira e outros membros da igreja matriz abriram essa congregação que se tornou independente no ano de 2012 e pode ser considerada uma igreja evangélica de cunho progressista.

Além de pastor, Henrique Vieira é filiado ao Partido Socialismo e Liberdade (PSOL) e foi candidato em 2012 a vereador da cidade de Niterói (RJ). Ganhou as eleições e exerceu seu mandato entre 2013 e 2016. Concorreu às eleições de 2016, mas não foi eleito e, desde o ano de 2017, é assessor de Marcelo Freixo (deputado estadual pelo Rio de Janeiro) $)^{5}$. Henrique Vieira também é colunista do Mídia Ninja, um grupo de mídia alternativa, e realizou uma série de vídeos que propunha uma reflexão sobre os evangélicos e seu envolvimento na sociedade. Vamos apresentar parte do conteúdo do seu primeiro vídeo, divulgado em junho de 2017, que tem como título "Nem todo evangélico é conservador", por ser ele paradigmático para entender o teor central de parte dos discursos formulados por evangélicos progressistas:

Não generalize os evangélicos. Nem todo evangélico é conservador. Existe um setor fundamentalista, extremista com poder político, econômico e midiático. Este setor representa um risco à democracia, aos direitos humanos e à diversidade. Um tipo de religiosidade violenta que não escuta e não dialoga. Baseada no confronto, não no encontro. Existem por aí uns coronéis da fé, mercadores da religião, que lucram e enriquecem às custas do sofrimento do povo. Existem por aí uns fiscalizadores dos corpos, mais apegados a uma doutrina do que ao amor e à dignidade humana. Nossa tarefa aqui é denunciar que este setor não representa a totalidade da experiência evangélica em nosso país. Existem evangélicos lutando pela democracia e pelo Estado Laico. Existem irmãos e irmãs lutando contra o racismo e afirmando que a Bíblia é um livro negro de interpretação tantas vezes brancas e racista. Existem irmãs lutando contra o patriarcado e o machismo, tão presentes no cristianismo ins- 
titucional. Existem irmãos e irmãs lutando contra o preconceito que impõe sofrimento e mata LGBTs todos os dias. Existem irmãos e irmãs que a partir de sua fé lutam por terra, moradia, direitos, cidadania, o pão de cada dia. [...]

Mas nossa tarefa aqui também é denunciar que o fundamentalismo não tem nada a ver com Jesus. Veja bem, Jesus foi pobre, da periferia, andou com os miseráveis e excluídos da sua época. Condenou o acúmulo de riquezas e venceu preconceitos históricos. Jesus foi preso, torturado, humilhado publicamente e assassinado pelo Império Romano a pedido de uma elite religiosa que o considerava desviado e herege. Jesus foi vítima da raiva dos fundamentalistas, do próprio Estado e daqueles religiosos que se sentiam donos, defensores e procuradores de Deus. Portanto, afirmar a memória e a vida de Jesus é desmontar esse castelo fundamentalista e resgatar esse sentido mais generoso e acolhedor do evangelho. Fazer isso também é importante especialmente em nosso tempo para defender a democracia, celebrar a diversidade, enfrentar os discursos de ódio e afirmar uma prática de amor e o amor com o próximo. ("Nem todo evangélico é conservador" 2017)

O trecho selecionado é longo, mas apresenta boa parte dos princípios que fundamentam os discursos de setores progressistas evangélicos. Um dos principais objetivos desse setor é disputar o significado do termo evangélico demonstrando que existem maneiras de experimentar a fé evangélica diferentes daquelas amplamente difundidas pela mídia e senso comum que associam pessoas dessa religião automaticamente ao conservadorismo. Por entender que "nem todo evangélico" é conservador, Henrique Vieira sustenta que existem, e deveriam existir ainda mais, evangélicos que lutam "pela democracia e pelo Estado Laico", "contra o racismo", "contra o patriarcado e o machismo", "contra o preconceito que impõe sofrimento e mata LGBTs" e que "a partir de sua fé lutam por terra, direitos, cidadania" em suas comunidades e contextos específicos. Esse discurso de Henrique Vieira dá o tom de boa parte das iniciativas evangélicas progressistas, uma vez que esse setor visa se articular de forma a demonstrar que ser evangélico deveria significar amplo engajamento social em prol da transformação da realidade política a partir da valorização dos princípios democráticos e de justiça social. Para se atingir esse ideal de ativismo político a partir da fé, os evangélicos progressistas entendem que é essencial se organizar para disputar dentro do segmento evangélico o significado que é ser um seguidor de Jesus.

Um exemplo de organização evangélica progressista que possui a função semelhante de demonstrar que nem todo evangélico é conservador é o coletivo Entre. nós formado e organizado por lideranças religiosas que atuam principalmente na cidade do Rio de Janeiro. Como nem todo evangélico é conservador, o Entre.nós tem por objetivo disputar o significado socialmente atribuído ao termo "evangélico". O 
coletivo se propõe a catalogar experiências de evangélicos progressistas que atuam social e politicamente em causas diversas e gravar e divulgar vídeos com o intuito de demonstrar que existem evangélicos preocupados com direitos humanos, luta contra a pobreza e a desigualdade social, em favor da justiça social e ampliação da cidadania. O Entre.nós surgiu em 2015 quando um grupo de evangélicos ligados a uma ONG chamada Viva Rio conseguiu apoio, inclusive financeiro, para se dedicar a um projeto específico que buscasse apresentar uma outra face dos evangélicos brasileiros pouco conhecida na grande mídia. Desde então, além de apresentar vídeos, textos e materiais sobre essa vertente evangélica que se diz engajada com a construção da cidadania, o grupo participa de atos públicos na região metropolitana do Rio de Janeiro e desenvolve eventos com a finalidade de aproximar pessoas cristãs evangélicas que lutam por direitos e justiça social através de uma rede na qual elas possam se conectar.

Entre as atividades propostas pelo Entre.nós, estão encontros que proporcionam debates a respeito das relações entre religião e sociedade como o que aconteceu em agosto de 2017 no Rio de Janeiro, chamado "Fé.Publik: Igreja, Evangelho e Cidade". De acordo com a descrição oficial, o evento procurava promover uma experiência que "priorize a criação de ideias, propostas, projetos e conteúdos que qualifiquem e potencializem as ações e serviços que as igrejas realizam na cidade, com a cidade, pelo bem comum na cidade" ${ }^{\text {. }} \mathrm{O}$ evento contou com a presença de lideranças religiosas, pastores, membros de igrejas interessados em refletir sobre essas questões e também de professoras universitárias e pesquisadoras, não evangélicas, que ofereceram informações mais técnicas a respeito de temas como direitos da cidade, juventude, violência urbana, mobilidade etc. $\mathrm{O}$ teor dos discursos formulados no evento era de que o cristão tinha como uma de suas tarefas refletir sobre assuntos de interesse público para que ele pudesse ser um ator de transformação social a favor da igualdade, direitos e cidadania dentro do espaço urbano onde sua igreja está inserida.

Outro coletivo evangélico progressista semelhante é o Esperançar que, assim como o Entre.nós, atua principalmente nas mídias sociais às quais são vinculados vídeos, entrevistas e textos que buscam "apresentar o evangelho a partir da ótica dos oprimidos da história”. O pastor Henrique Vieira é um dos colaboradores do Esperançar que pretende realizar um contraponto aos setores mais conhecidos da religião evangélica e que apresentam um discurso marcado por "retrocessos, ataques aos direitos humanos e intolerância" . O material teológico promovido pelo Esperançar pretende apresentar as ligações que o evangelho possui com noções como justiça social e cidadania e convoca os fiéis e igrejas a se envolverem na construção de um novo mundo. Enquanto o Entre.nós tinha como foco principal divulgar iniciativas de cristãos que estivessem engajados em causas sociais sem realizar reflexões teológicas mais profundas, o Esperançar visa construir os contornos teóricos que devem balizar a atuação cristã evangélica na sociedade e, por isso, divulga conteúdos teológicos que confrontam abertamente teologias consideradas mais conservadoras. 
Os aportes teológicos principais do Esperançar, de Henrique Vieira e de outras lideranças evangélicas progressistas é a chamada Teologia da Libertação e as Teologias Contextuais que estão na base de seus discursos teológicos, sociais e políticos. A noção da Teologia da Libertação de que "Deus fez uma opção preferencial pelos pobres", conforme proferido na Conferência de Puebla em 1979 (Terceira Conferência do Episcopado Latino-Americano que foi um importante encontro de ministros e teólogos), e de que a libertação trazida pelo evangelho não é só religiosa e espiritual, mas social, política e econômica, faz parte da retórica constante de evangélicos progressistas. Sendo assim, ser um seguidor de Jesus implica se envolver com a cultura e com a sociedade de forma a sustentar valores ligados aos direitos humanos, democracia e cidadania. As Teologias Contextuais podem ser entendidas como desdobramentos da Teologia da Libertação que intentam chamar a atenção para as categorias sociais que atravessam o sujeito que crê. Com o intuito de contextualizar a mensagem cristã contida na Bíblia para as situações sociais e concretas dos sujeitos, a Teologia Contextual desenvolve, por exemplo, uma "teologia negra", uma "teologia feminista", uma "teologia queer", entre outros. Ao mobilizar tais teologias, os agentes evangélicos progressistas acreditam que estão aproximando a leitura e a interpretação da Bíblia das situações reais de vida das pessoas que estão em situação de mais fragilidade social, como homossexuais, negros, pobres, mulheres, imigrantes etc.

Além da disputa teológica por meio da qual são apresentadas algumas ideias tanto da Teologia da Libertação quanto das teologias contextuais, o Esperançar entende ser papel do cristão promover reflexões sobre a situação social conjuntural. Por isso, esses cristãos devem produzir uma análise a partir da fé sobre temas como racismo, violência urbana, desigualdades sociais e pobreza, por exemplo, principalmente em cidades como o Rio de Janeiro e outras metrópoles que vivenciam esses problemas em seu cotidiano. A chave interpretativa para discutir esses temas de relevância social é a Teologia da Libertação e as Contextuais, que trazem a percepção teológica de que é necessário haver uma atuação da igreja e do fiel no sentido de romper com aquilo que são consideradas as estruturas opressoras da sociedade. Os membros do Esperançar sustentam, a partir de suas bases teológicas, que Deus interfere na história para trazer uma libertação que não é apenas espiritual, mas também social. Na interpretação dos evangélicos progressistas, se Deus age e interfere na história a favor dos oprimidos e contra os opressores, essa deveria ser a forma que o cristão e a igreja deveriam agir e interferir na sociedade na qual estão inseridos.

Para ficar em um exemplo de como isso é feito, o Esperançar, em busca de cumprir com seus ideais, esteve engajado com as lutas judiciais envolvendo o pedido do habeas corpus a Rafael Braga ${ }^{8}$. Em uma live realizada no Facebook no dia 3 de agosto de 2017, o pastor Henrique Vieira juntamente com o teólogo evangélico progressista Ronilso Pacheco realizaram uma reflexão social e teológica a respeito da situação de Rafael Braga, na qual enfatizaram ser uma necessidade de a igreja buscar direitos e justiça àqueles que não tiveram acesso a ela: 
Nós enxergamos, pela fé, no evangelho, na história do êxodo, na história de Jesus de Nazaré, no grito dos profetas, que existe um grito de Deus em favor dos oprimidos e em protesto contra a opressão. Isso é espiritual. Muita gente diz que isso é ativismo político, mas para nós é testemunho de fé que se materializa na atividade humana que quer a gente queira ou não queira é política.

A nossa militância política está inspirada na tradição do êxodo, no grito dos profetas, na encarnação de Deus em Jesus Cristo de Nazaré. É isso que nos anima e nos faz enxergar no grito do Rafael [Braga] o semblante de Deus. Nos faz perceber o protesto de Deus contra esse aparato legal que é profundamente racista e elitista. Os que decidem, decidem a partir de um contexto de privilégio. (fala retirada de uma live realizada no dia 3 de agosto de 2017).

Verifica-se que o engajamento na campanha pela liberdade de Rafael Braga passa a ser visto como uma tarefa confiada por Deus ao fiel, uma vez que, na interpretação teológica em questão, Jesus está do lado dos oprimidos e dos pobres e, portanto, da justiça social. Os evangélicos progressistas estão pouco preocupados em desenvolver uma ética do domínio na qual "dominar" setores estratégicos da sociedade percebidos como espaços pecaminosos a serem convertidos para Jesus e combater formas "seculares" de envolvimento com a cultura é o esforço principal. Ao contrário, o engajamento social dos progressistas evangélicos é baseado em princípios religiosos que pretendem "defender a vida onde ela se encontra vulnerável". Na retórica de suas lideranças, valores como "liberdade", "democracia", "igualdade", "cidadania" são os fundamentos do cristianismo e deve compor a missão do cristão. Cabe, portanto, aos evangélicos progressistas cristãos e à igreja utilizar os valores do amor, misericórdia, paz e justiça para pensar questões estruturantes presentes nas realidades sociais e situações econômicas e políticas como as que se apresentam na América Latina e em especial no Brasil. Da mesma forma como foi verificado no caso da Frente de Evangélicos pelo Estado de Direito, Henrique Vieira, o Entre.nós e o Esperançar não priorizam as atividades evangelizadoras com o foco na conversão de indivíduos. Esse aspecto praticamente não apareceu na retórica dos grupos e líderes que estudei. Isso porque a preocupação maior é instruir aquele que já é evangélico em uma ética religiosa que possui implicações políticas do que propriamente modificar a identidade religiosa das pessoas.

Tanto o Entre.nós quanto o Esperançar são redes de evangélicos que militam em prol dos direitos humanos, democracia e cidadania, principalmente no Rio de Janeiro e Niterói. No primeiro caso, o do Entre.nós, busca-se realizar uma plataforma através da qual iniciativas de evangélicos engajados socialmente sejam compartilhadas e possam receber apoio de pessoal, financeiro ou mesmo simbólico através de incentivos. No segundo, o Esperançar aglutina teólogos e pastores que divulgam seus 
discursos teológicos e políticos para confrontar abertamente visões que consideram conservadoras a respeito da fé evangélica. Nos dois casos, intenta-se fazer uma espécie de contraponto aos evangélicos hegemônicos que consideram ser uma religião fundamentalista. Ambos os grupos perderam muito fôlego na segunda metade de 2018. Quando parte desta pesquisa foi feita em 2017, existia uma expectativa de que as duas plataformas fossem capazes de juntar em torno de si lideranças evangélicas progressistas que compartilhassem iniciativas e reforçassem seus ideais e valores. No entanto, acredito que essa pretensão não foi verificada na prática, já que a conjuntura do país se modificou bastante fazendo com que as estratégias de engajamento dos evangélicos progressistas mudassem também. Por se tratar de coletivos que dependiam da articulação de certos líderes, quando alguns deles saíram do país por conta de projetos pessoais ou quando alguns mudaram de estratégias passando a atuar em outras frentes, os coletivos foram também perdendo força. Em setembro de 2018, nem o Entre.nós nem o Esperançar estavam atuando de forma tão enfática como os seus articuladores esperavam em meados de 2017. Henrique Vieira, ao contrário, até setembro de 2018 parecia estar bem consolidado como uma liderança evangélica progressista capaz de representar parte dos discursos deste setor de alguma maneira.

Os evangélicos progressistas possuem como seus principais interlocutores os evangélicos majoritários e mais conservadores. É a eles que tecem suas críticas, disputam o significado do que é ser evangélico e buscam apresentar o que entendem ser novas maneiras de vivenciar a espiritualidade evangélica. Para que sejam capazes de se apresentar perante o seu próprio segmento religioso, os evangélicos progressistas necessitam realizar traduções dos seus discursos sobre democracia e direitos humanos para uma retórica e gramática religiosa evangélica. É necessário fazer com que as categorias seculares como democracia, cidadania, direitos sejam traduzidas em termos religiosos. Os evangélicos progressistas, para se legitimarem diante do setor evangélico majoritário, não podem abrir mão da gramática religiosa e, por isso, a todo instante, precisam fazer referência a passagens, versículos e narrativas da Bíblia para poder validar a forma de atuação na sociedade e conseguir desenvolver a consciência política que querem alcançar. Sem que os termos seculares sejam incorporados na retórica religiosa, os progressistas perderiam sua legitimidade no seu referido segmento religioso e seriam automaticamente classificados como militantes disfarçados de religiosos.

Além de adaptarem seus discursos político e social através de menções a elementos tradicionais da religião evangélica, os líderes e coletivos evangélicos progressistas precisam adaptar seus discursos para as demandas de uma sociedade laica e secular de maneira que suas categorias religiosas necessitam de tradução para serem aceitas de forma legítima na esfera pública. Sendo assim, tanto a Frente de Evangélicos pelo Estado de Direito quanto líderes e o pastor Henrique Vieira precisam traduzir sua linguagem religiosa para a retórica da democracia, cidadania, direitos humanos, justiça social etc. Deste modo, ambos os atores religiosos passam a se dotar de legitimidade perante movimentos sociais, partidos políticos e segmentos universi- 
tários como uma voz evangélica com a qual podem compartilhar princípios políticos e sociais semelhantes. Uma vez traduzidas suas posições teológicas e religiosas para a gramática secular dos direitos e da democracia, os discursos dos evangélicos progressistas passam a ser aceitos e até desejados no interior de articulações sociais não religiosas. É comum verificar a presença de líderes evangélicos progressistas em eventos organizados por organizações não religiosas que buscam uma referência evangélica que valide suas posições políticas.

Os evangélicos progressistas têm se inserido na esfera pública buscando introduzir novas concepções sobre a fé e desenvolver significados teológicos inovadores que são capazes de fortalecer a identidade de cristãos de esquerda. Muitos cristãos evangélicos alinhados às posições de esquerda disseram se sentir deslocados em suas comunidades de fé mais conservadoras por conta de suas maneiras de pensar. Ao participar de coletivos evangélicos progressistas, o fiel aprende uma gramática apropriada para seu envolvimento social e político sem que isso entre em contradição com sua concepção religiosa. Esta nova consciência política teológica evangélica progressista permite que esses cristãos conciliem suas identidades seculares marcadas pelo ativismo político mais à esquerda com a identidade evangélica. Deste modo, os evangélicos progressistas aprofundam tanto seus compromissos políticos e sociais quanto seu pertencimento à fé evangélica.

A presença dos progressistas evangélicos na sociedade demonstra as disputas existentes no interior do campo evangélico brasileiro. Uma vez que a grande maioria dos evangélicos atua social e politicamente tendo por base a ética da dominação que possui como foco a manutenção de valores morais conservadores, a proteção dos interesses religiosos e a oposição a pautas como descriminalização do aborto, diversidade sexual, feminismo, entre outros, os grupos que estamos analisando precisam disputar o próprio sentido do que significa ser evangélico. Nessa disputa, não se pode abrir mão de referenciais que compõem a identidade evangélica, como oração, leitura bíblica, santidade, referência a textos das escrituras, canções, entre outros, sob o risco de perder a legitimidade perante o público evangélico. Esses termos, portanto, são ressignificados teologicamente para se enquadrar às demandas dos direitos humanos e da cidadania, visto que mobilizar uma retórica secular a respeito dessa temática sem a devida tradução para o contexto religioso evangélico seria sacramentar um estigma de que tais agentes não são verdadeiros evangélicos. Passagens da Bíblia que geralmente são utilizadas em alguns meios evangélicos para condenar a prática homossexual, por exemplo, são lidas e interpretadas a partir de novas chaves que demonstram que, por ser Jesus a favor da vida e da liberdade, a prática sexual não deveria ser condenada. Além disso, muitas passagens da Bíblia são contadas a partir do ponto de vista das pessoas pobres e marginalizadas, enfatizando-se o papel de Deus de lutar em favor de tais pessoas. $\mathrm{Na}$ disputa em torno do significado do que é ser evangélico, os progressistas não podem renunciar à necessária articulação dos seus princípios políticos e sociais com a gramática religiosa evangélica mais tradicional para se conectar com o público evangélico. 
Neste sentido, ao analisar a Frente de Evangélicos pelo Estado de Direito e os discursos do pastor Henrique Vieira, é possível ver um exemplo de como progressistas evangélicos atuam no espaço público brasileiro em busca de interlocuções com setores conservadores da sociedade muitas vezes inacessíveis a movimentos sociais e partidos de esquerda. Uma vez que é mantida a identidade evangélica em seu ativismo social e político, os evangélicos progressistas almejam legitimidade tanto no meio evangélico quanto na esfera pública. Por mais minoritários, pouco articulados e com poucos recursos, ao desenvolverem as estratégias de traduzir sua mensagem política para uma gramática religiosa conservadora, os evangélicos progressistas apresentam um caso interessante para se pensar as relações entre religião e sociedade e fazer avançar as discussões a respeito da temática nos estudos sobre evangélicos no Brasil.

\section{Conclusão}

Neste trabalho, procuramos discutir e analisar como grupos evangélicos progressistas em seus discursos e ações pretendem resistir e confrontar uma forma de espiritualidade evangélica por eles considerada conservadora e fundamentalista. De acordo com as interpretações dos coletivos e lideranças apresentados ao longo deste texto, o envolvimento do cristão e das igrejas na sociedade deve se pautar pela defesa da vida, da justiça social e da democracia. Fundamentados em um pensamento teológico que sustenta que Deus estaria do lado dessas pautas e que existem narrativas a respeito do assunto na Bíblia, esses evangélicos envolvem-se com a cultura não para converter indivíduos, nem para conservar princípios morais que estão ameaçados, nem tampouco para dominar setores estratégicos da sociedade e convertê-los para Jesus. $O$ teor do discurso apresentado pela Frente de Evangélicos pelo Estado de Direito e pelo pastor Henrique Vieira é o de que os evangélicos devem se envolver na sociedade para transformá-la a partir de princípios e valores religiosos que articulam fé e defesa da democracia e da cidadania.

Por mais que o termo progressista com que são rotulados tais agentes religiosos possa ser inadequado, uma vez que aos olhos de militâncias de esquerda e movimentos sociais eles ainda poderão ser considerados conservadores, é possível perceber que se trata de um tipo de discurso bem diferente do que tradicionalmente é veiculado pelos setores mais hegemônicos da religião evangélica. $\mathrm{O}$ primeiro achado deste trabalho é que a religião evangélica é de fato muito plural e apresenta uma variedade discursiva no que tange a temas sociais e políticos. Desta pluralidade, embates passam a se acirrar dentro do segmento evangélico no qual se verifica a disputa pelo próprio significado do que é ser evangélico e de qual deve ser o papel da igreja e do fiel diante da sociedade. Do ponto de vista dos coletivos progressistas, os conservadores estariam em nome da moral, deixando de lado o amor e a paz e proferindo discursos de ódio contra minorias e contra a diversidade. Do ponto de vista dos evangélicos mais conservadores, os progressistas estariam desvirtuando os 
propósitos da fé ao trazer para a religião discussões advindas de segmentos seculares da sociedade.

Outro ponto que é possível perceber a respeito dos atores evangélicos progressistas é que seu modelo de espiritualidade está arraigado na ideia de que o cristão evangélico deve atuar política e socialmente na construção de uma sociedade mais democrática e cidadã. Seria papel da igreja, na interpretação dos evangélicos progressistas, expandir direitos civis para grupos minoritários, adotar discursos que valorizem a diversidade e a pluralidade, desenvolver uma consciência política de que é necessário lidar com questões estruturais para mitigar os efeitos das desigualdades sociais, violência urbana, pobreza etc. Trata-se de um modelo de espiritualidade que declaradamente se diz atravessada por elementos políticos. Há que se ressaltar que, embora haja alguns líderes progressistas, como o próprio Henrique Vieira, que disputam cargos públicos, a maior parte do ativismo político evangélico progressista se dá nos canais mais informais de participação pública. Se os grupos pentecostais e neopentecostais alcançaram espaços de representação no poder legislativo e executivo de maneira significativa nas últimas décadas, as organizações evangélicas progressistas até o momento em que este trabalho foi redigido (setembro de 2018) não pleiteiam a política institucional e a disputa por cargos. Antes, sua atuação ocorre no esforço de construção de uma consciência política evangélica capaz de influenciar o cristão na forma como ele atua na sociedade.

Este trabalho demonstra que conhecer de forma mais aprofundada outras vozes existentes no segmento evangélico do país pode auxiliar a compreensão das disputas religiosas em curso em nossa sociedade. Por mais minoritários e pouco expressivos que sejam os evangélicos progressistas, a análise de seus discursos permite aprofundar o debate sobre temas caros para a sociologia da religião, como a relação que grupos religiosos estabelecem com a esfera pública e com a sociedade mais ampla. Neste caso, percebe-se que, ao discutir os contornos do que é ser evangélico e de como este deve se relacionar com a sociedade, os evangélicos progressistas estão engajados no desenvolvimento de uma espiritualidade que confronta os aportes conservadores e tradicionais que balizam o comportamento e visões de mundo dos setores mais hegemônicos da religião evangélica. Acompanhar o desenvolvimento dos confrontos surgidos a partir dessas disputas é uma tarefa ainda por fazer e que trará para a literatura especializada a respeito do tema novas luzes para se pensar a presença evangélica na sociedade brasileira.

\section{Referências Bibliográficas}

CAMARGO, Cândido Procópio. (1971), Igreja e Desenvolvimento. São Paulo: CEBRAP. CAMARGO, Cândido Procópio (Org.). (1973), Católicos, protestantes, espíritas. Petrópolis: Vozes.

CAMPOS, Leonildo. (2004), "Evangélicos, pentecostais e carismáticos na mídia radiofônica e televisiva”. Revista USP, no 61: 146-163. 
CAMPOS, Leonildo. (2005), "As origens norte-americanas do pentecostalismo brasileiro". Revista USP, no 67: 100-115.

CAMURÇA, Marcelo. (2013), "O Brasil religioso que emerge do Censo de 2010: consolidações, tendências e perplexidades". In: F. Teixeira; R. Menezes (orgs.). Religiões em Movimento. Petrópolis: Vozes.

CAVALCANTE, Ronaldo. (2010), A Cidade e o Gueto: Introdução a uma teologia pública protestante e o desafio do neofundamentalismo evangélico no Brasil. São Paulo: Fonte Editorial.

CONRADO, Flávio. (2006), Religião e cultura cívica: um estudo sobre modalidades, oposições e complementariedades presentes nas ações sociais evangélicas no Brasil. Rio de Janeiro: Tese de Doutorado em Antropologia Cultural, UFRJ.

CUNHA, Magali do Nascimento. (2007), A explosão gospel: um olhar das ciências humanas sobre o cenário evangélico no Brasil. Rio de Janeiro: Mauad X.

CUNHA, Magali do Nascimento. (2017), "Política, mídia e religião: o ativismo progressista entre evangélicos brasileiros por meio do Facebook e do Twitter". Comunicação Ë Sociedade, vol. 39, n 3: 217-244.

D’EPINAY, Christian Lalive. (1970), O Refúgio das Massas. Rio de Janeiro: Paz \& Terra.

FRESTON, Paul. (1999), "Neo-Pentecostalism" in Brazil: Problems of Definition and the Struggle of Hegemony". Archives de Sciences Sociales des Religions, vol. 105: 145-162.

GIUMBELLI, Emerson. (2002), O fim da religião: dilemas da liberdade religiosa no Brasil e na França. São Paulo: Attar.

GIUMBELLI, Emerson. (2008), "A presença do religioso no espaço público: modalidades no Brasil”. Religião Eु Sociedade, vol. 28, no 2: 80-101.

GIUMBELLI, Emerson. (2013), "Cultura pública: evangélicos y su presencia en la sociedad brasileña". Sociedad y Religión, vol. 23, nำ 40: 13-43.

MARIANO, Ricardo. (2011), "Sociologia do crescimento pentecostal no Brasil: um balanço". Perspectiva Teológica, ano 43, no 119: 11-36.

MARIANO, Ricardo. (2012), Neopentecostais: Sociologia do novo pentecostalismo no Brasil. São Paulo: Edições Loyola.

MARIZ, Cecília. (1999), "A teologia da Batalha espiritual: uma revisão da bibliografia". Revista Brasileira de Informação Bibliográfica em Ciências Sociais, vol. 47, no 1: 33-48.

MENDONÇA, Antonio Gouvêa. (2004), "Protestantismo brasileiro, uma breve interpretação histórica". In: B. M. Souza; L. M. S. Martino. Sociologia da religião e mudança social: católicos, protestantes e novos movimentos religiosos no Brasil. São Paulo: Paulus.

PADILLA, René; COUTO, Péricles. (2011), Igreja: agente de transformação. Curitiba: Missão Aliança.

ROSAS, Nina. (2015), Cultura evangélica e "dominação" do Brasil: música, mídia e gênero no caso do Diante do Trono. Belo Horizonte: Tese de Doutorado em Sociologia, UFMG.

SANCHES, Regina. (2009), Teologia da Missão Integral: História e Método da Teologia Evangélica Latino Americana. São Paulo: Editora Reflexão.

SCHELIGA, Eva Lenita. (2010), Educando sentidos, orientando uma práxis: etnografia das práticas assistenciais de evangélicos brasileiros. São Paulo: Tese de Doutorado em Ciência Social (Antropologia Social), USP.

SOUZA, Beatriz Muniz. (1969), A Experiência da Salvação: Pentecostais em São Paulo. São Paulo: Duas Cidades.

VELASQUES FILHO, Prócoro; MENDONÇA, Antonio Gouvêa. (1990), Introdução ao protestantismo no Brasil. São Paulo: Loyola.

\section{Sites consultados}

FRENTE DE EVANGÉLICOS PELO ESTADO DE DIREITO. (2016) "Manifesto Missão na Íntegra". Frente de Evangélicos pelo Estado de Direito, Documento Google Docs. Disponível em: https://docs. 
google.com/forms/d/1_cX_NWSpA4dd_icb0Bi3_iBl2JhAWFshOOOeckJr_IA/viewform?edit_requested $=$ true. Acesso em: 28/09/2018.

FRENTE DE EVANGÉLICOS PELO ESTADO DE DIREITO. (2018), "Nota da Frente de Evangélicos pelo Estado de Direito: Pode um crente votar em Bolsonaro?". Facebook da Frente de Evangélicos pelo Estado de Direito, 28 set. 2018. Disponível em: https:/www.facebook.com/frentedeevangelicos/ posts/1058868897609132?_tn__K-R. Acesso em: 28/09/2018.

\section{Vídeos consultados}

VIEIRA, Henrique. (2017), Nem todo Evangélico é Conservador. Mídia Ninja. Disponível em: https:// www.youtube.com/watch?v=Nn7ZPUKn3mI\&spfreload=10. Acesso: 03/09/2017.

VIEIRA, Henrique; PACHECO, Ronilso. (2017), "Bate-papo com Ronilso Pacheco e Henrique Vieira sobre Jesus e Rafael Braga: Pensar o evangelho e justiça a partir da teologia negra". Facebook do Esperançar, 3 ago. 2017. Disponível em: https://www.facebook.com/1713313515554256/videos/1984510348434570/. Acesso: 03/09/2017.

\section{Notas}

1 Adotamos o uso do termo "evangélico" como uma categoria abrangente tal como preconizado por Ricardo Mariano, que afirma que "o termo evangélico, na América Latina, recobre o campo religioso formado pelas denominações cristãs nascidas na e descendentes da Reforma Protestante europeia do século XVI. Designa tanto as igrejas protestantes históricas (Luterana, Presbiteriana, Congregacional, Anglicana, Metodista e Batista) como as pentecostais (Congregação Cristã no Brasil, Assembleia de Deus, Evangelho Quadrangular, Brasil Para Cristo, Deus é Amor, Casa da Bênção, Universal do Reino de Deus, etc)". (Mariano 2012:10). Neste sentido, iremos denominar de evangélicos os grupos progressistas aqui estudados e pentecostais e protestantes quando fizermos menção específica às correntes ligadas a essas tradições.

2 É possível perceber a presença de protestantes no Brasil antes do século XIX, como no caso do chamado protestantismo de invasão que aportou no Nordeste junto com a invasão holandesa. No entanto, foi só com as missões do século XIX que o protestantismo lançou raízes no país desenvolvendo igrejas, lideranças e fazendo prosélitos.

3 A Teologia da Missão Integral é um ramo da teologia protestante que enfatizou que a fé deve possuir desdobramentos em diversos âmbitos da vida, inclusive sociais e políticos. A fé evangélica, no entendimento dos teólogos da Missão Integral, deve tratar integralmente os sujeitos considerando suas dimensões sócio-históricas.

4 Embora não haja consenso sobre o que seja liberalismo teológico, alguns teólogos da Missão Integral consideram uma vertente que, por assumir eixos de análise externos - filosofia, psicologia, antropologia, sociologia - à Bíblia para aplicar em sua interpretação, relativizou a autoridade do texto considerado sagrado ou viu seu caráter de autoridade com um olhar diferenciado (Padilla e Couto 2011).

5 Vale ressaltar que este trabalho foi escrito entre agosto e setembro de 2018 com dados obtidos desde 2016 de forma que, quando o leitor estiver lendo, pode ser que Henrique Vieira esteja desenvolvendo outros projetos e tenha outra ocupação.

6 Informação retirada do panfleto entregue no dia do evento para os participantes e divulgado nas redes sociais.

7 Essas informações foram retiradas das falas dos próprios membros do grupo em espaço como Facebook e mesmo pessoalmente.

8 Rafael Braga é um jovem que foi preso no Rio de Janeiro no contexto das manifestações de 2013. Na época com 25 anos, foi detido por portar duas garrafas de plástico contendo Pinho Sol e desinfetante que foi considerado pela polícia como material explosivo utilizado em coquetéis molotov. Preso desde então, militantes dos direitos humanos, advogados e vários grupos da sociedade civil sustentam que, por ser pobre e negro, Rafael Braga foi vítima de racismo que permeia as instituições policiais e jurídicas do país e realizam campanhas pedindo seu habeas corpus e sua soltura. 
Gustavo de Alencar* (gcpalencar@gmail.com)

* Doutor em Sociologia pela Universidade Federal de Minas Gerais (UFMG), Belo Horizonte, MG, Brasil. 


\section{Resumo:}

\section{Grupos protestantes e engajamento social: uma análise dos discursos e ações de coletivos evangélicos progressistas}

A inserção dos evangélicos na sociedade é um tema bastante debatido na sociologia da religião do Brasil. Devido à pouca homogeneidade que o caracteriza, é possível identificar no movimento evangélico coletivos que, na contramão do que se poderia esperar de seus adeptos, comumente associados ao conservadorismo, defendem os direitos humanos, a justiça social, a cidadania e a democracia. Neste trabalho, iremos apresentar alguns desses grupos para analisar seus discursos e práticas. Serão apresentados os discursos das lideranças de grupos paraeclesiásticos evangélicos recolhidos através de trabalho de campo realizado entre 2016 e 2018. Lançar luz sobre essa vertente do protestantismo pode contribuir para uma maior compreensão das dinâmicas do campo religioso brasileiro em geral e dos evangélicos em particular.

Palavras-chave: protestantismo; cultura pública; evangélicos progressistas

\section{Abstract:}

\section{Protestant Groups and Social Engagement: an analysis of progressive evangelical discourse and collective action}

The interpolation of evangelicals in society is a controversial theme in Sociology of Religion in Brazil. Due to the lack of homogeneity that characterizes it, it is possible to identify within the evangelical movement collectives that, to the contrary of what one might expect of its members, commonly associated with conservatism, defend human rights, social justice, citizenship and democracy. In this work, we aim to present some of these groups to analyze its discourse and practices. We shall present non ecclesiastic evangelical group's leadership discourse obtained through field work between 2016 and 2018. To shed some light over this branch of protestantism may contribute to a better understanding of the Brazilian religious field dynamics in general and of evangelicals in particular.

Keywords: protestantism; public culture; progressive evangelicals 